\title{
Different Gene Expression of Potassium Channels by Thyroid Hormone and an Antithyroid Drug Between the Atrium and Ventricle of Rats
}

\author{
Mei Lei MA, ${ }^{1}$ MD, Kenichi Watanabe, ${ }^{1}$ MD, Hiroshi Watanabe, ${ }^{2}$ MD, \\ Yukio HosAKA, ${ }^{2}$ MD, Satoru KomurA, ${ }^{2}$ MD, Yoshifusa AIZAWA, ${ }^{2}$ MD, \\ and Tadashi YAMAMOTO, ${ }^{3} \mathrm{MD}$
}

\section{SUMMARY}

Thyroid hormone has been shown to modulate the gene expression of cardiac potassium channels, however, it is not known if gene expression is different between the atrium and the ventricle. The long-term effects of thyroid hormone on nuclear thyroid hormone receptors are also not known.

Triiodothyronine (T3) at $25 \mu \mathrm{g} / 100 \mathrm{~g}$ of body weight or propylthiouracil (PTU) at 4 $\mathrm{mg} / 100 \mathrm{~g}$ of body weight was given to adult rats via a gastric tube for 14 days. The levels of mRNA of Kv1.2, Kv1.4, Kv1.5, Kv2.1, Kv4.2, erg, LQT1, and minK were assayed by RNase protection assay. The mRNA of nuclear T3-receptor- $\alpha 1$ and T3-receptor- $\beta 1$ were also assayed for 15 days.

After T3 (or PTU), plasma free T3 and free T4 increased (or decreased) significantly. The mRNA levels of Kv1.2 and Kv1.4 were reduced after T3 in the atrium and the ventricle, while PTU increased the levels in both chambers. Kv1.5 was significantly up-regulated by T3 in the atrium and the ventricle $(P<0.02$ for both) and PTU decreased its expression in the ventricle $(P<0.02)$. Kv2.1 and Kv4.2 were not affected by T3 or PTU.

mRNA of erg was not affected by $\mathrm{T} 3$ in the atrium but decreased in the ventricle $(P<0.01)$. After PTU, erg mRNA was decreased in the atrium $(P<0.02)$ but increased in the ventricle $(P<0.01)$. LQT1 was decreased by T3 in both chambers $(P<0.01)$ and not affected by PTU. minK was not detectable in the control state and was up-regulated only in the atrium: a peak on the 4th day followed by a decline to the undetectable level on the 10-15th days.

During T3 treatment, nuclear T3-receptor- $\alpha 1$ and $\beta 1$ mRNA were decreased in the initial 3 days but returned to control levels thereafter.

Conclusions: Between the atrium and ventricle of the adult rat heart, the responses of gene expression of voltage-gated potassium channels to T3 or PTU were quantitatively or qualitatively different and the differential responses may explain cardiac manifestations of

From the ${ }^{1}$ Department of Clinical Pharmacology, Niigata College of Pharmacology, ${ }^{2}$ Division of Cardiology and ${ }^{3}$ Renal Research Institute, Graduate School of Medical and Dental Science, Niigata University, Niigata, Japan.

Address for correspondence: Yoshihisa. Aizawa, MD, Division of Cardiology Graduate School of Medical and Dental Science Niigata University, Asahimachi, Niigata, 951-8510 Japan.

Received for publication March 25, 2002.

Revised and accepted July 15, 2002. 
hyperthyroidism, which is a frequent complication of supraventricular arrhythmia. (Jpn Heart J 2003; 44: 101-110)

Key words: Cardiac potassium channel, mRNA, RNase protection assay, Thyroid hormone, Propylthiouracil

AN in situ hybridization study showed many potassium channels in ferret cardiac myocytes, although with diversity ${ }^{1)}$ and even in distinct regions of the heart, the molecular basis of potassium channels seemed to vary from cell to cell. Such diversity must be relevant to the shape of the action potential of the cardiac myocytes. Among them, Kv1.2, Kv1.4, Kv1.5, Kv2.1, Kv4.2, LQT1, and erg have been observed in all anatomic regions of the heart. ${ }^{1-3)}$

Thyroid hormone is known to affect cardiovascular function and has been shown to affect the gene expression of ionic currents of cardiac cells. ${ }^{4-8)}$

In a preliminary study, ${ }^{8)}$ we confirmed the modulation of gene expression of the voltage-gated potassium channels (Kv1.2, Kv1.4, Kv1.5, Kv2.1 and Kv4.2) by thyroid hormone and an antithyroid drug in rat ventricles. As an extension of this earlier study, we measured the mRNA levels of these $\mathrm{K}^{+}$channels as well as those of erg, LQT1, and minK separately in rat atrium and ventricle after triiodothyronine (T3) administration or administration of the antithyroid drug propylthiouracil (PTU). The serial changes in nuclear T3-receptors were also determined.

\section{MATERIALS AND Methods}

Animals: Twelve week old female Wister Kyoto (WKY) rats were administered $25 \mu \mathrm{g}$ of L-triiodothyronine (T3) (Takeda Chemical Industries, Ltd.,Tokyo) per $100 \mathrm{~g}$ of body weight. T3 was dissolved in distilled water and given via a gastric tube for up to 14 days. The control rats received only distilled water by the same method. To simulate hypothyroidism, the antithyroid drug propylthiouracil (PTU) was given at $4 \mathrm{mg}$ per $100 \mathrm{~g}$ of body weight via a gastric tube for 14 days $(n=8)$. This investigation was conducted in accordance with the Guidelines for the Care and Use of Laboratory Animals published by the US National Institute of Health.

The effects of T3 on the mRNA levels of nuclear receptors of thyroid hormone (TR $\alpha 1$ and TR $\beta 1)$ were also studied in other rats $(n=28)$.

Plasma thyroid hormones and heart rate: Blood pressure and heart rate were measured by an automated blood pressure analyzer (BP-98A, Soflon Co. Ltd., Japan) immediately before sacrificing the rats at the end of administration of T3 or PTU. Blood was collected by cardiac puncture under ether anesthesia and plasma free $\mathrm{T} 3$ and free $\mathrm{T} 4$ were measured by radioimmunoassay (RIA). 
Isolation of RNA: The heart was rinsed in PBS to remove excess blood and divided into the atrium, including the left and right atrial appendages and the ventricle, as reported previously. ${ }^{8)}$ Each atrial sample was obtained from 2 rats but each ventricle sample was obtained from a single rat. Total cellular RNA was prepared by the acid guanidinium-phenol-chloroform method.

cDNA cloning of potassium channels and nuclear T3 receptors: Rat cDNA for voltage-gated potassium channels and nuclear T3 receptors (TR $\alpha 1$ and TR $\beta 1$ ) was cloned by reverse transcriptase-polymerase chain reaction (RT-PCR). Total RNA isolated from the normal rat ventricle was reversely transcribed to cDNA using an oligo-dT primer. Table I shows the primers synthesized for the cloning of rat voltage-gated potassium channel cDNA fragments.

Using the cDNA as templates and primers, cDNA was amplified by PCR and the cDNA was cloned in a pBluescript II SK ${ }^{+}$vector (Stratagene, San Diego, $\mathrm{CA}$ ). The sequences of the cloned genes were examined by an automated DNA sequencer (ABI 373A; Perkin-Elmer Japan, Urayasu, Japan). As a rat housekeeping gene, glyceraldehyde-3-phosphate dehydrogenase (GAPDH) cDNA (kindly provided by Dr. R. Wu, Cornell University, Ithaca, NY), 114 bp in length and corresponding to 673 to 787 was subcloned in a pGEM 3Z vector (Promega Co., Madison, WI). The plasmids were linearized with EcoR I (Kv1.2, Kv1.4, and Kv1.5) or BamH I (Kv2.1, Kv4.2, minK, ERG, LQT1, and GAPDH).

RNase protection assay: Ten $\mathrm{mg}$ of total cellular RNA and tRNA (Promega Co.) was hybridized with ${ }^{32} \mathrm{P}$-labeled Kv1.2, Kv1.4, Kv1.5, Kv2.1, Kv4.2, minK, erg, LQT1, TR $\alpha 1$ and TR $\beta 1$ antisense RNA probes $\left(1 \times 10^{5}\right.$ counts $/ \mathrm{min}$ each) combined with a GAPDH antisense probe, synthesized by in vitro transcription using linearized templates, at $45^{\circ} \mathrm{C}$ overnight, and then unhybridized probes were

Table I. Primers Synthesized for Cloning of Rat Voltage-gated Potassium Channels and GADPH

\begin{tabular}{lcllcc}
\hline Channel & $\begin{array}{l}\text { Length } \\
\text { (base pairs) }\end{array}$ & Sequence & Vector & $\begin{array}{l}\text { RNA } \\
\text { polymerase }\end{array}$ & $\begin{array}{l}\text { Accession \# } \\
\text { GenBank }\end{array}$ \\
\hline Kv1.2 (RBK2) & 258 & $1143-1401$ & pBIISK $^{+}$ & T3 & JO4731 \\
Kv1.4 (RHK1) & 232 & $673-905$ & pBIISK $^{+}$ & T3 & M32867 \\
Kv1.5 (KV1) & 347 & $2394-2741$ & pBIISK $^{+}$ & T3 & M27158 \\
Kv2.1 (drk1) & 417 & $1536-1953$ & pBIISK $^{+}$ & T7 & X16476 \\
Kv4.2 (Rshall) & 397 & $1962-2359$ & pBIISK $^{+}$ & T7 & S64320 \\
minK & 243 & $158-401$ & pBIISK $^{+}$ & T7 & M36461 \\
LQT1 & 250 & $259-509$ & pBIISK $^{+}$ & T7 & U92655 \\
erg & 260 & $2440-2700$ & pBIISK $^{+}$ & T7 & Z96106 \\
TR $\alpha 1$ & 291 & $905-1196$ & pBIISK $^{+}$ & T7 & X12744 \\
TR $\beta 1$ & 240 & $1821-2061$ & pBISK $^{+}$ & T7 & J03933 \\
GADPH & 114 & $673-787$ & pGEM3Z & T7 & M17701 \\
\hline
\end{tabular}


digested with ribonuclease A $(0.3 \mathrm{mg} / \mathrm{mL}$; Sigma, St. Louis, MO) and ribonuclease T1 (30 units/mL; GIBCO/BRL, Grand Island, NY) at $30^{\circ} \mathrm{C}$ for 1 hour. The ribonuclease was inactivated with proteinase K-treatment $(0.5 \mathrm{mg} / \mathrm{mL}$, Promega Co.) at $37^{\circ} \mathrm{C}$ for 30 minutes. After phenol-chloroform extraction and ethanol precipitation, the hybridized probes protected from the ribonuclease digestion were denatured at $85^{\circ} \mathrm{C}$ for 3 minutes and electrophoresed on $6 \%$ polyacrylamide gels. The dried gels were exposed to x-ray film (Fuji photo Film Co., Ltd. Tokyo) at $70^{\circ} \mathrm{C}$ for 20 hours to detect potassium channel mRNA followed by exposure to new x-ray film for 6 hours to detect GAPDH mRNA.The autoradiography bands were analyzed by computerized densitometry using NIH Image software (1.59, NIH Division of Computer Research and Technology, Bethesda, MD) to quantitate each mRNA expression.

Data are presented as a ratio of specific mRNA (exposed for 20 hours) to GAPDH mRNA (exposed for 6 hours) to equalize the quantity of RNA within each sample.

Statistical Analysis: Values are presented as the mean \pm SD. The Mann-Whitney U test was used to compare data between unpaired samples and $P<0.05$ was considered Statistically Significant.

\section{RESULTS}

Plasma T3 and T4 levels and heart rate: Plasma free T3 levels were significantly higher in the 14-day T3-treated rats than in the controls: $147.2 \pm 20.9 \mathrm{pg} / \mathrm{dL}$ vs $2.8 \pm 0.2 \mathrm{pg} / \mathrm{dL}(P<0.001)$. Free T4 levels were also higher but the difference was not significant: $0.8 \pm 0.2 \mathrm{ng} / \mathrm{dL}$ vs $0.5 \pm 0.2 \mathrm{ng} / \mathrm{dL}(P<0.05)(n=8)$. In the PTU treated rats $(n=8)$, plasma free T3 fell to $0.9 \pm 0.0 \mathrm{pg} / \mathrm{dL}$ at the end of 2 weeks of administration $(P<0.001)$. Plasma free T4 similarly fell to $0.2 \pm 0.0 \mathrm{ng} / \mathrm{dL}$ $(P<0.01)$.

Heart rate was significantly increased after T3 treatment from $393 \pm 29$ beats/ min to $501 \pm 35$ beats $/ \mathrm{min}(P<0.002)$. Heart rate did not change significantly after PTU: $372 \pm 30 \mathrm{bpm} / \mathrm{min}$ vs $398 \pm 10 \mathrm{bpm} / \mathrm{min}$.

Nuclear T3-receptors: $\operatorname{TR} \alpha 1$ and TR $\beta 1$ receptors in the atrium were measured serially ( $n=28$ ). Both TR $\alpha 1$ and TR $\beta 1$ showed initial decreases in mRNA levels during T3 treatment, as reported by earlier workers. ${ }^{9)}$ However, within 3 days, the mRNA levels increased towards the control level and stayed at that level thereafter (Figure 1).

Potassium channel mRNA: (1) Kv1.2 Gene: Kv1.2 mRNA was 3-fold higher in the atrium than in the ventricle $(n=8)$ and T3 treatment decreased the mRNA level in the two chambers (Figure 2). After PTU treatment $(n=8)$, it increased 1.8-fold in the atrium $(P<0.02)$ and 2.2 -fold in the ventricle (NS). 


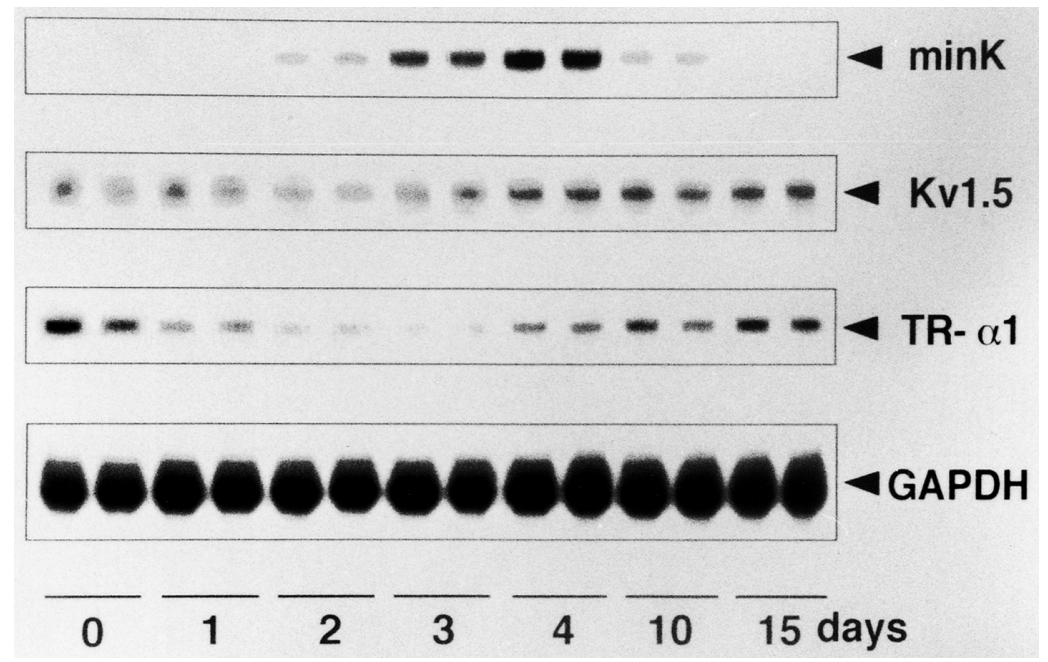

Figure 1. Time courses of TR $\alpha 1$, minK, and Kv1.5 in the atrium. T3-receptor (TR $\alpha 1$ ) and TR $\beta 1$ (not shown) showed transient decreases. Time courses of minK mRNA and Kv1.5 are shown together. GAPDH was 4 times overexposed (see text).
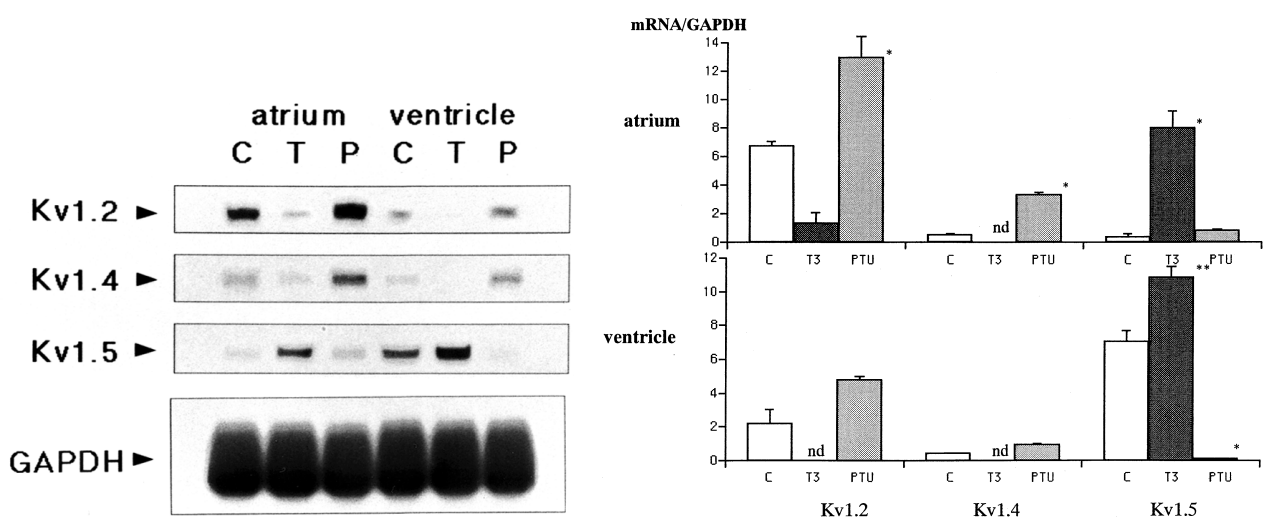

Figure 2. mRNA of voltage-gated potassium channels in the atrium and ventricle (Kv1.2, Kv1.4, K1.5). T3 and PTU showed reciprocal effects on Shaker family (Kv1.2, Kv1.4 and Kv1.5). Kv2.1 and Kv4.3 were not affected by T3 or PTU. GAPDH was 4 times overexposed (see text).

(2) Kv1.4 Gene: Kv1.4 mRNA was detected, although only slightly, in both the atrium and ventricle $(0.5 \pm 0.1$ and $0.4 \pm 0.02$, respectively) and was decreased by T3 to an undetectable level. Kv1.4 mRNA was significantly increased by PTU [6.6-fold in the atrium and 2.3-fold in the ventricle $(P<0.01$ for both chambers)] (Figure 2).

(3) Kv1.5 Gene: In the control rats, Kv1.5 mRNA was higher in the ventricle than in the atrium ( $6.8 \pm 0.6$ vs $0.7 \pm 0.2)$ and was increased by T3-treatment to $10.9 \pm 0.6$ 
in the ventricle $(P<0.02)$ and $8.0 \pm 1.2$ in the atrium $(P<0.02)$. PTU caused a decrease in the ventricle to $0.1 \pm 0.01(P<0.02)$ but caused little change in the atrium (0.6 \pm 0.1$)$ (Figure 2). The time course of Kv1.5 is shown in Figure 1.

(4) Kv2.1 and Kv4.2 Genes: Kv2.1 and Kv4.2 mRNA levels were almost the same in both chambers $(2.6 \pm 0.3$ vs $3.6 \pm 0.1$ for Kv2.1 in the atrium and $2.2 \pm 0.2$ vs $2.4 \pm 0.1$ for Kv4.2 in the ventricle, respectively). They were not altered by $\mathrm{T} 3$ or PTU in either chamber (Figure 2).

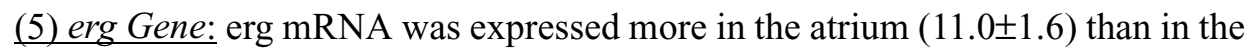
ventricle $(6.5 \pm 0.3)$ (Figure 3 ). The mRNA level was not altered by T3 in the atrium but was decreased by PTU $(P<0.02)$. In the ventricle, the erg mRNA level was decreased by 0.4 -fold of the control by $\mathrm{T} 3$ and was increased 1.3 -fold by PTU $(P<0.01$ for both).

(6) LQT1 mRNA: KvLQT1 mRNA was expressed both in the atrium $(9.3 \pm 0.5)$ and in the ventricle $(13.5 \pm 0.8)$ in the control (Figure 3 ) and was decreased by T3 by 0.5 -fold of the control in the atrium and by 0.25 -fold in the ventricles $(P<0.01$ for both). PTU caused no change in either chamber.

(7) $\min K$ : In the control rats, $\operatorname{minK}$ mRNA was undetected in the atria and ventricles and T3 induced gene expression only in atria (Figure 4). PTU did not induce the expression of minK in either chamber. The level of minK reached a peak on

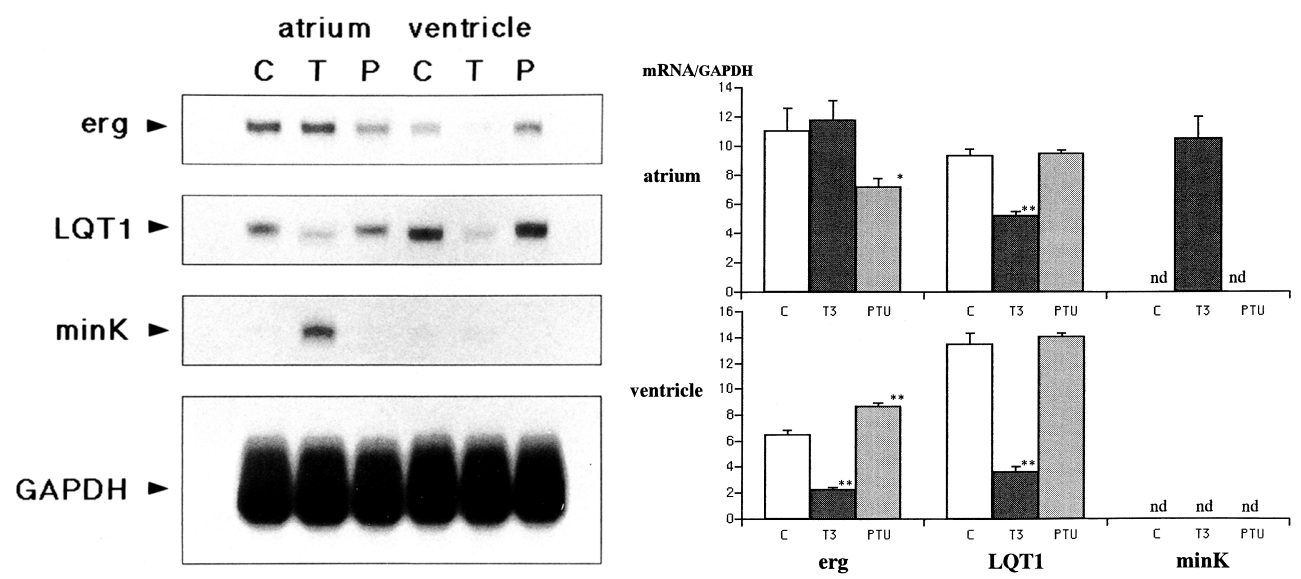

Figure 3. ERG, KvLQT1 and minK. The effects of $\mathrm{T} 3$ and PTU on erg mRNA level was different between the atrium and ventricle. minK was transiently expressed in the atrium GAPDH was 4 times overexposed (see text). 
Table II. Summary of Changes of Voltage-gated Potassium Channels by Triiodothyronine (T3) and Propylthiouracil (PTU)

\begin{tabular}{|c|c|c|c|c|c|c|}
\hline \multirow[t]{2}{*}{ mRNA } & \multicolumn{3}{|c|}{ Atrium } & \multicolumn{3}{|c|}{ Ventricle } \\
\hline & $\mathrm{C}(n=8)$ & T3 $(n=8)$ & PTU $(n=8)$ & $\mathrm{C}(n=8)$ & T3 $(n=8)$ & PTU $(n=8)$ \\
\hline Kv1.2 & $6.7 \pm 0.3$ & $1.3 \pm 0.8$ & $12.9 \pm 1.5^{*}$ & $2.2 \pm 0.8$ & nd & $4.8 \pm 0.2$ \\
\hline Kv1.4 & $0.5 \pm 0.1$ & nd & $3.3 \pm 0.3 * *$ & $0.4 \pm 0.0$ & nd & $0.9 \pm 0.1 * *$ \\
\hline Kv1.5 & $0.7 \pm 0.2$ & $8.0 \pm 1.2 *$ & $0.6 \pm 0.1$ & $6.8 \pm 0.6$ & $10.9 \pm 0.6^{*}$ & $0.1 \pm 0.0^{*}$ \\
\hline Kv2.1 & $2.6 \pm 0.3$ & $2.8 \pm 0.1$ & $2.6 \pm 0.4$ & $3.6 \pm 0.1$ & $3.6 \pm 0.1$ & $3.6 \pm 0.2$ \\
\hline $\mathrm{Kv} 4.2$ & $2.2 \pm 0.2$ & $2.1 \pm 0.1$ & $2.2 \pm 0.2$ & $2.4 \pm 0.1$ & $2.3 \pm 0.2$ & $2.2 \pm 0.1$ \\
\hline erg & $11.0 \pm 1.6$ & $11.8 \pm 1.3$ & $7.2 \pm 0.6^{*}$ & $6.5 \pm 0.3$ & $2.3 \pm 0.1 * *$ & $8.7 \pm 0.2 * *$ \\
\hline LQT1 & $9.3 \pm 0.5$ & $5.2 \pm 0.3^{* *}$ & $9.5 \pm 0.2$ & $13.5 \pm 0.8$ & $3.6 \pm 0.4^{* *}$ & $14.1 \pm 0.2$ \\
\hline $\min K$ & nd & $10.5 \pm 1.5$ & nd & nd & nd & nd \\
\hline
\end{tabular}

Ratios of specific mRNA to GAPDH mRNA are represented as mean \pm SD. nd $=$ not detectable, *: $P<0$ 02. **: $P<0.01$.

approximately days 3-4, and was barely found on days 10 and 15 . The time courses of the minK, Kv1.5 and TR $\alpha 1$ are presented in Figure 1. The data are summarized in Table II.

\section{DISCUSSION}

The levels of $\mathrm{K}^{+}$channel mRNA have been found to be expressed differently between the atrium and ventricle in adult rats: Kv1.2, Kv1.4, and Kv1.5 were reported to be expressed more in the atrium than in the ventricle ${ }^{1-3)}$ while Kv 2.1 and Kv 4.2 were expressed more in the ventricle. The present study has demonstrated less expression of Kv1.5 in the atrium than expected, however, after T3 treatment it increased 20-fold. Kv2.1, Kv4.2, LQT1, and erg were similarly expressed in the two chambers in the control state.

In the atrium, the dominant currents of repolarization are considered to be Ito, ${ }^{10)} \mathrm{IKs}, \mathrm{IKr},{ }^{11-13)}$ and Ikur, ${ }^{14)}$ although the direct relationship between the mRNA levels of the corresponding $\mathrm{K}^{+}$channels and the shape of the action potential is not clear from the results of the present study or from those of previous studies. ${ }^{1-3,8)}$

Modulation of the gene expression of cardiac $\mathrm{K}^{+}$channels was very similar to that of previous studies, ${ }^{4-8)}$ however, these studies were only performed in the ventricle. We assayed separately the mRNA of potassium channels of the atrium and ventricle. There were quantitative and qualitative differences in the responses between the atrium and the ventricle.

In brief, the Shaker family of $\mathrm{K}^{+}$channels was regulated positively (Kv1.5) and negatively (Kv1.2 and Kv1.4) by T3 ${ }^{8,15)}$ and the increase in Kv1.5 mRNA by 
T3 was greater in the atrium than in the ventricle. PTU produced the opposite effects. Though Ojamaa, et al reported that KV1.5 was not increased by thyroid hormone, ${ }^{7)}$ our data, including that from a previous study ${ }^{8)}$ and that of other workers, ${ }^{16)}$ have shown increased levels of Kv1.5 mRNA after T3 treatment. ${ }^{9)}$ The reason for such a discrepancy is not evident, however, the increase in Kv1.5 mRNA would be a factor which shortens the action potential duration. Kv2.1 and Kv4.2 mRNA were not affected by T3 or PTU in the two chambers, although Shimoni, et al reported an increase in Kv4.2 by T3 and considered it to be the cause of shortening of action potential of the rat ventricle. ${ }^{4)}$

The mRNA of erg was detectable both in the atrium and the ventricle, however, T3 decreased it in the ventricle. LQT1 mRNA was similarly decreased by T3 in the two chambers and slightly increased by PTU.

minK mRNA was not detected in the basal state in the two chambers but a transient increase was observed in the atrium. It is worth noting that minK which was cloned first from the kidney, ${ }^{17)}$ was confirmed to exist in the heart, although only during the neonatal period. ${ }^{18)}$ The significance of the transient increase in minK is not clear since minK is considered to function as an IKs after association with LQT1, ${ }^{19,20)}$ even though the latter was found to decrease in both chambers.

We were unable to predict the changes in the shape or duration of the action potential from the overall changes in the gene expression of cardiac $\mathrm{K}^{+}$channels. So far, thyroid hormone has been shown to have a direct effect on cardiac ionic currents $^{21-23)}$ but the shortened action potential duration in the rat cardiac myocytes is considered to be due to the modulation in gene expression of $\mathrm{K}^{+}$channels. ${ }^{24,25)}$ Among the changes in gene expression of $\mathrm{K}^{+}$channels, the increased expression of Kv1.5 (Ikur) is most likely a cause of the shortening of the action potential duration in the rat. ${ }^{24-26)}$ PTU showed essentially the opposite effect on these $\mathrm{K}^{+}$channel genes.

From a clinical perspective, if the atrium has a shorter action potential duration, it would provide a basis for atrial fibrillation ${ }^{27,28)}$ and explain the frequent complication of atrial fibrillation in hyperthyroidism. On the other hand, shortening of the action potential duration in the ventricular muscle and concomitant tachycardia may render the ventricle susceptible to developing heart failure known as thyrotoxic heart. ${ }^{29,30)}$ Possible modulation of other gene expressions such as calcium channels or $\beta$-adrenergic receptors and their intracellular signaling transduction systems by thyroid hormone needs to be studied.

Such gene expression of the cardiac $\mathrm{K}^{+}$channels must be through the binding of T3 to a specific nuclear receptor. T3 is believed to decrease T3 receptor mRNA. ${ }^{9)}$ In the present study, a decrease in nuclear receptors was confirmed, but it was followed by a recovery to the basal level on days 10-15 (Figure 1). 
In conclusion, the thyroid hormone T3 (and the antithyroid drug PTU) was shown to affect the gene expression of voltage-gated cardiac potassium channels in the adult rat, although the responses seemed to be different between the atrium and ventricle. Chamber specific responses of gene expression of potassium channels may explain the characteristics of the cardiac manifestations of hyperthyroidism.

\section{ACKNOWLEDGEMENTS}

This work was partly supported by a grant from the Ministry of Welfare and Health of Japan and also by a grant from the Ministry of Culture, Sports and Education.

\section{REFERENCES}

1. Brahmajothi MV, Morales MK, Liu S, Rasmusson R, Campbell DL, Strauss HC. In situ hybridization reveals extensive diversity of $\mathrm{K}^{+}$channel mRNA in isolated ferret cardiac myocytes. Circ Res 1996; 78: 1083-9.

2. Dixon JE, McKinnon D. Quantitative analysis of potassium channel mRNA expression in atrial and ventricular muscle of rats. Circ Res 1994; 75: 252-60.

3. Barry DM, Trimmer JS, Merlie JP, Nerbonne JM. Differential expression of voltage-gated $\mathrm{K}^{+}$channel subunits in adult rat heart. Relation to functional $\mathrm{K}^{+}$channel. Circ Res 1995; 77: 361-9.

4. Shimoni Y, Fiset C, Clark RB, Dixon JE, McKinnon D, Giles WR. Thyroid hormone regulates postnatal expression of transient $\mathrm{K}^{+}$channel isoforms in rat ventricle. J Physiol 1990; 500: 65-73.

5. Matsubara H, Suzuki L, Inada M. Shaker-related potassium channels, Kv1.4, mRNA regulation in cultured rat heart myocytes and differential expression of Kv1.4 and Kv1.5 genes in myocardial development and hypertrophy. J Clin Invest 1993; 92:1659-66.

6. Nishiyama A, Kambe F, Kamiya K, et al. Effects of thyroid and glucocorticoid hormones on Kv1.5 potassium channel gene expression in the rat left ventricle. Biochem Biophys Res Commun 1997; 237: 521-6.

7. Ojamaa K, Sabet A, Kenessey A, Shenoy R. Regulation of rat cardiac Kv1.5 gene expression by thyroid hormone is rapid and chamber specific. Endocrinology 1999; 140; 3170-6.

8. Abe A, Yamamoto T, Isome M, et al. Thyroid hormone regulates expression of Shaker-related potassium channel mRNA in rat heart. Biochem Biophys Rapid Comm 1998; 245: 226-30.

9. Balkman C, Ojamaa K, Klein I. Time course of the in vitro effects of thyroid hormone on cardiac gene expression. Endocrinology 1992; 130: 2001-6.

10. Campbell DL, Rasmusson RL, Comer MB, Strauss HC. The cardiac calcium-independent transient outward potassium current: kinetics, molecular properties, and role in ventricular repolarization. In Zipes DP, Jalife J, editors. Cardiac Electrophysiology: From Cell to Bedside. $2^{\text {nd }}$ Ed. Philadelphia, PA: WB Saunders Co, 1995; 83-96.

11. Balser JR, Bennett PB, Roden DM. Time-dependent outward current in guinea pig ventricular myocytes. J Gen Physiol 1990; 96: 835-63.

12. Sanguinetti MC, Jurkiewicz NK. Delayed rectifier outward $\mathrm{K}^{+}$current is composed of two currents in guinea pig atrial cells. Am J Physiol 1991; 260: H393-9.

13. Wang Z, Fermini B, Nattel S. Rapid and slow components of delayed rectifier current in human atrial myocytes. Cardiovasc Res 1994; 28: 1540-6.

14. Wang Z, Fermini B, Nattel S. Sustained depolarization-induced outward current in human atrial myocytes: evidence for a novel delayed rectifier $\mathrm{K}^{+}$current similar to Kv1.5 cloned channel currents. Cir Res 1993; 73: 106176.

15. Williams GR, Brent GA. Specificity of nuclear hormone receptor action: who conducts the orchestra? J Endocrinol 1992 Nov; 135: 191-4. 
16. Selby L, Choy AM, Moerike KE, Roden DM. $\mathrm{K}^{+}$channel "isoform switching" with thyroid hormone treatment, but not with hypothyroidism or amiodarone. Circulation 1994; 90: I-416 (absrtact).

17. Takumi T, Ohkubo H, Nakanishi S. Cloning of a membrane protein that induces a slow voltage-gated potassium current. Nature 1988; 242: 1042-5.

18. Folander K, Smith JS, Antanavage J, Bennett C, Stein RB, Swanson R. Cloning and expression of the delayedrectifier Isk channel from neonatal rat heart and diethylstilbesterol-primed rat uterus. Proc Natl Acad Sci USA 1990; 87: 2975-9.

19. Brahani J, Lesage F, Guillemare E, Fink M, Lazdunski M, Romey G. KvLQT1 and Isk (minK) proteins associate to form the IKs cardiac potassium current. Nature 1996; 384: 78-80.

20. Sanguinetti MC, Curran ME, Zou A, et al. Coassembly of KvLQT1 and minK (IsK) proteins to form cardiac Iks potassium channel. Nature 1996; 384: 80-3.

21. Sakaguchi Y, Cui G, Sen L. Acute effects of thyroid hormone on inward rectifier potassium channel currents in guinea pig ventricular myocytes. Endocrinology 1990; 137: 4744-51.

22. Craelius W, Green WL, Harris DR. Acute effects of thyroid hormone on sodium currents in neonatal myocytes. Biosci Rep 1990; 10: 309-15.

23. Dudley SC, Baumgarten CM. Bursting of cardiac sodium channels after acute exposure to 3,5,3'-triiodo-L-thyronine. Circ Res 1993; 73: 301-13.

24. Arnsdorf MF, Cilders RW. Atrial electrophysiology in experimental hyperthyroidism in rabbits. Cir Res 1970; 17: $575-81$

25. Johnson PN, Fredberg AS, Marshall JM. Action of thyroid hormone on the transmembrane potentials from sinoatrial node cells and atrial muscle cells in isolated rabbits. Cardiology 1973; 58: 273-89.

26. Watanabe H, Meiloe MA, Washizuka T, Hosaka Y, Chinushi M, Aizawa Y. Regulation of L-type calcium channel expression and current by short term administration of thyroid hormone. PACE 2002 (in press).

27. Rensma PL, Allessie MA, Lammers WJEP, Bonke FIM, Schalij MJ. Length of excitation wave and susceptibility to reentrant atrial arrhythmias in normal conscious dogs. Cir Res 1988; 62: 395-410.

28. Wjffels MCEF, Kirchhof CJHJ, Dorland R, Allesie MA. Atrial fibrillation begets atrial fibrillation. A study in awake chronically instrumented goats. Circulation 1995; 92: 1954-68.

29. Poliker R Burger AG, Scherrer U, Nicod P. The thyroid and the heart. Circulation 1993; 87: 1435-41.

30. Klein I. Thyroid hormone and the cardiovascular system. Am J Med 1990; 88: 631-2. 